\title{
TRANSFER PRICING DECISION: MANUFACTURING COMPANIES WITH SPECIAL TRANSACTION ON THE INDONESIAN STOCK EXCHANGE
}

\author{
Anny Widiasmara \\ Universitas PGRI Madiun, Kota Madiun, Indonesia \\ anny.asmara@gmail.com \\ Ika Purwaningsih \\ Universitas PGRI Madiun, Kota Madiun, Indonesia \\ ikapurwaningsih800@gmail.com
}

\begin{abstract}
The purpose of this study is to provide empirical evidence on the influence of taxes, tunneling incentives for income shifting, financial reporting and intangible assets on transfer pricing decisions. The data used is secondary data in the form of annual financial statements downloaded from the official website of IDX www.idx.co.id. The population of this study is a manufacturing company registered in IDX for the period 2016-2018. Sample selection technique using purposive sampling method so that 33 companies are obtained according to the criteria. The analysis technique uses multiple linear regressions tested with SPSS version 20 applications. The results showed that taxes, tunneling incentives for income shifting, and financial reporting had no effect on transfer pricing decisions. Meanwhile, intangible assets have a significant positive effect on transfer pricing decisions.
\end{abstract}

\section{Keywords}

tax; tunneling incentive for income shifting; financial reporting; intangible assets; transfer pricing

\section{JEL Classification}

M41; G12

\section{Introduction}

This research aims to provide empirical evidence on the influence of taxes, tunneling incentives for income shifting, financial reporting and intangible assets on transfer pricing decisions using a sample of manufacturing companies registered in IDX for the period 2016-2018. Transfer pricing is basically a neutral concept, i.e. the price charged between divisions or intersegments in the same organization for the exchange of products and services. However, if an exchange involves a multinational, interdivision, or intersegment company that crosses the tax jurisdiction of a different country, then the multinational company is motivated to act non-neutral to the exchange price. This motivation arises because there are economic benefits, namely overall tax cost savings (Tampubolon \& Al Farizi, 2018).

The definition of transfer pricing in terms of taxation is pricing for intra-corporate purposes that occurs in affiliated companies. Differences in tax rates between countries present an opportunity for business entities to take advantage of the difference in rates by shifting income or fees from business entities in high-tax countries to other business entities in a group in a tax haven country in order to save tax costs (Tampubolon \& Al Farizi, 2018). (Jacob, 1996) found a link between the amount of tax paid and the reported profit and the volume of interstate transactions in multinational corporations. If companies use transfer pricing to minimize their global taxes, then the companies 
that have the greatest chance of manipulating profits are companies with large amounts of international inter-company sales and large differences in interstate tax rates as well. Transfer pricing can also be applied to companies in one group .

Transfer pricing can lead to a decrease in state income from the tax revenue sector, whereas tax is the highest source of income of the country (Refrizal, 2019). The issuance of SE-04/PJ.07/1993 and KMK-650/KMK.04/1994 regarding the list of tax haven countries is the beginning of the Indonesian government's attention to transfer pricing practices. The increasing seriousness of the Indonesian government in paying attention to transfer pricing is evidenced through the issuance of Law No. 36 of 2008 on Income Tax. The rules on transfer pricing are further detailed in Regulation of the Director General of Taxation No. 32 of 2011 which is an update to Regulation of the Director General of Taxation No. 43 of 2010 (Setiawan, 2014). G-20 countries have agreed to work together to fix loopholes that can be exploited by transfer pricing actors through the creation of a transparent international taxation system, namely with the publication of Base Erosion and Profit Shifting (BEPS) Action by the Organization .

Noviastika research (2016) shows the influence of taxes on transfer pricing decisions. The chances of running transfer pricing will increase if the tax rate imposed by a country is so high that a company that makes a large profit is motivated to transfer its profits to its affiliated entities located in a low-tax country. In contrast to the above research, Melmusi's research (2016) shows no tax influence on transfer pricing decisions. Companies can take ways other than transfer pricing, among others by implementing tax planning to reduce the tax burden. Tunneling is the transfer of resources out of the company for the personal benefit of controlling shareholders (Johnson et al., 2000). (Gilson \& Gordon, 2003) disclosed that controlling shareholders may take several steps to fulfill their personal interests through controlling the company's operational policies such as dividends, salaries, bonuses, and

The company's transfer pricing decisions were also influenced by financial reporting which in this study was projected with a bonus plan. Bonus plan is one of the accounting strategies aimed at the projectation of directors' compensation through efforts to increase the company's overall profits. Bonuses are awarded on the basis of the profits achieved, so it is logical that directors attempt to manipulate the company's profits in order to maximize their remuneration receipts and bonuses. Transfer pricing may result in one subunit or division experiencing losses (Hartati et al., 2014). Marisa (2017) did not find any effect of bonus plan on transfer pricing decisions. The awarding of bonuses based on profit does not motivate the company's board of directors to maximize the company's profit with the transfer pricing mechanism. Meanwhile, Melmusi (2016) found the effect of bonus plan on transfer pricing decisions.

The definition of intangible assets according to PSAK 19 is a nonmonary asset identified without physical existence. Intangible assets are difficult to assess, so royalty transfers are also difficult to assess based on arm's length. Intangible assets have certain characteristics such as lack of established markets and subjective valuations thus increasing the opportunity of intangible assets transfer between companies in tax jurisdictions in contrast to transfer pricing mechanisms (Richardson et al., 2013).

Jafri and Mustikasari (2018) found there was no intangible assets influence on transfer pricing decisions. The intangible value of large assets does not encourage managers to take transfer pricing decisions. Intangible assets are functioned as additional information to minimize the information gap between controlling shareholders and noncontrolling shareholders. In contrast to the results of the above study, Fadhilah (2018) found that there is a significant influence on intangible assets on transfer pricing decisions. The intangible assets value is directly proportional to the transfer pricing decision. 


\section{Literature and development overview transfer pricing hypothesis}

Transfer pricing is pricing in inter-party transactions that have a special relationship (Regulation of the Director General of Taxation, 2011). (Kurniawan, 2015) defines transfer pricing as the company's policy in setting the price of an inter-party transaction that has a special relationship. (Tampubolon \& Al Farizi, 2018) defines transfer pricing as a product or service exchange transaction that occurs between two different entities within a group of companies. (Suandy, 2016) distinguishes the definition of transfer pricing into two, namely neutral and pejorative definitions. In a neutral definition, transfer pricing is assumed to be a purely business tactic and strategy by not aiming to reduce the tax burden. In the pejorative definition, transfer pricing is assumed to be an attempt to save tax burdens using tactics, one of which is to shift profits to low-tax countries. In general, the term transfer pricing tends to lead to manipulation of transfer pricing, which is the practice of determining transfer value not based on market forces which has an impact on saving the total tax burden of a group of companies as a whole through the transfer of accounting profits or tax revenue from higher tax jurisdictions to tax jurisdictions. lower (Suwanto, 2012).

(Circular Letter of the Director General of Taxation, 1993) states that the reasonableness of transfer pricing practices can be made on the sale price, purchase price, administrative and general fee quota or on overhead costs, interest charged on loans to the owner, payment of commissions, licenses, franchises, leases, royalties, rewards for management services, engineering, and other services, purchase of company assets by the owner at prices below normal prices, exports with third party intermediaries that lack/have no business substance.

The central issue of transfer pricing is the issue of pricing or pricing. Fiskus and other tax authorities want to ensure that between companies that have a special relationship or who do not have a special relationship will use a fair price in every trade transaction. If the company does not apply a reasonable price, a country's fiss will potentially lose revenue from the tax withdrawal sector. Fair pricing is a reference to the most valid exchange pricing for inter-party transactions that have a special relationship (Tampubolon \& Al Farizi, 2018).

(Regulation of the Director General of Taxation, 2011) defines fair price or fair profit as price or profit in inter-party transactions that do not have a special relationship in comparable circumstances, or price or profit in accordance with the principle of fairness and custom of business (ARM's Length Principle/ALP), which is the principle that requires the similarity of price or profit in transactions between parties that have or do not have a special relationship if there is a similarity or commencment of the situation. The establishment of a special relationship is when one party is in control or has significant influence over the other party in financial and operational decision making (Ikatan Akuntan Indonesia, 2014d). (Suandy, 2016) declares a special relationship established between the parent company and a subsidiary company or branch office or representative office either located domestically or abroad. The regulation on special relationships is found in (Law of the Republic of Indonesia, 2008) article 18 paragraphs (3), (3a), and (4).

The utilization of transfer pricing by taxpayers is feared to reduce the potential for state tax receipts. Therefore, it is necessary to make a transfer price agreement for reasonable market pricing. Advance Pricing Agreement (APA) is an agreement made by the Directorate General of Taxation together with the taxpayer or tax authorities of other countries in determining the parameters of fair price or fair profit in front of the parties who have a special relationship (Pohan, 2013).

\section{Tax}

Tax is a mandatory contribution to a country owed by a private person or entity that is coercive on the basis of the Law, without obtaining direct benefits and utilized in 
fulfilling the state's budget for the large amount of people's welfare (Law of the Republic of Indonesia, 2009). Prof. Dr. Rochmat Soemitro, S.H. defines taxes as people's dues to state coffers under the law (which can be imposed) by not obtaining direct lead services (counterpresentations) that can be shown and which are utilized for the payment of public expenditures (Mardiasmo, 2016).

Tax is defined as dues without obtaining lead services (counterpresentations) that can be directly demonstrated and utilized for the payment of public expenditures (Supramono \& Damayanti, 2010). Prof. Dr. P.J.A Andriani defines taxes as dues to the state (which can be imposed) owed by those who are obliged to pay them according to the regulations, by not regaining achievement, can be directly appointed, and useful to pay various public expenses related to the obligation of the state to run the government. According to Prof. Dr. MJH. Tax smeets are an achievement to governments that are owed through common norms, can be imposed, without any contrarepancies that can be shown individually, which is intended to finance government spending (Agoes \& Trisnawati, 2013).

\section{Tunneling incentive for income shifting}

(Rahmawati, 2016) defines tunneling as a term used to describe the actions of controlling shareholders who are looking for ways to take "profits" without the knowledge of non-controlling shareholders (adverse selection). Controlling shareholders are legal entities and/or individuals and/or business groups with a percentage of shareholdings more than equal to $25 \%$ of the total outstanding shares and have voting rights or shareholdings smaller than $25 \%$ but are shown to have exercised control both directly and indirectly (Bank Indonesia Regulation, 2012).

The term Tunneling was originally used to describe the conditions of the takeover of non-controlling shareholder rights in the Czech Republic. Tunneling is the transfer of assets and profits outside the company for the benefit of controlling shareholders. Tunneling can be categorized into two forms. First, controlling shareholders can transfer business entity resources into theirs through transactions between entities and owners through fraud, asset sales, transfer price contracts that bring benefits to controlling shareholders, overly large executive salaries, loan guarantees, takeover of corporate opportunities, etc. Second, controlling shareholders can multiply their shares even if they do not supply assets at all by issuing dilutive shares, minority freeze-outs, insider trading, and creeping acquisitions thus making noncontrolling shareholders loss (Johnson et al., 2000).

Corporate loans are the main form of tunneling in Chinese listed companies. The Chinese-listed holding company encouraged its subsidiaries to become registered companies by using the sale of related party goods and services to raise revenue in the pre-IPO period. This is motivated by tunneling opportunities in the post-IPO period, namely exploiting the economic resources of noncontrolling shareholders for the benefit of controlling shareholders. Tunneling is done by often not paying down debts to their listed subsidiaries thus making this the main reason for the early death of many new listed companies (Aharony et al., 2010).

(La Porta et al., 2000) mentions tunneling incentive for income shifting can occur in some form. For example, "inside" (a term for managers and controlling shareholders) sells additional outputs, assets, or securities in companies under their control to their other companies below normal prices. Tunneling incentives for income shifting can also include transfer of corporate opportunities, placing family members who may not qualify in managerial positions, or overpaying executives. 


\section{Financial reporting (bonus plan)}

Bonuses include one type of short-term employee benefit, namely employee benefits (except severance) that are expected to be completed entirely in less than a year after the annual reporting period during which the related services provided by employees expire (Ikatan Akuntan Indonesia, 2014c). Bonuses are additional income aimed at improving employee morale in improving work performance and loyalty to companies that are generally only awarded once a year. Bonuses are only awarded if the company makes a profit during the fiscal year that has passed and is not given evenly, but rather depends on the achievement of the individual's work (Mulyapradana \& Hatta, 2016). Business unit manager bonuses can be based on the company's total profit or on the profit of the business unit or the combined two. This is based on the argument that the manager's decisions and actions have more of a direct impact on his own business unit, rather than on other business units. However, this approach can hinder cooperation between units (Anthony \& Govindarajan, 2011). Bonuses can be based on the performance of a particular person or group that has many members, such as a working group, profit center, or even a company as a unit. The most commonly used possibility is the performance metrics in the annual bonus plan (Merchant \& Van der Stede, 2018). Income-based bonus schemes are a common method used to reward company executives. The bonus scheme allows management to decide on accounting and accrual policies that can maximize their bonus receipts (Healy, 1985).

\section{Intangible assets}

Intangible assets are nonmonary assets identified without physical form. Intangible assets have the main characteristic of objects that cannot be seen and held. Intangible assets can be recognized by the entity if the entity has the possibility to benefit financially in the future from that asset as well as the value of the asset or the amount of expenditure that must be spent in order to obtain it can be credible. The intangible assets include patents, copyrights, brands (trade marks), goodwill, franchises, and so on (Agoes \& Trisnawati, 2013).

(Indonesian Institute of Accountants, 2014b) defines intangible assets as assets that usually have a long economic lifespan, have no form, are beneficial in the company's operations and their use is not for trading. Intangible property consists of patents, trademarks, trade names, designs, and models. In addition, intangible property also includes literature or literature and rights to artistic ownership and intellectual property rights (OECD, 2010). Multinational corporations think strategically to relocate their intangible assets to affiliated business entities based in low-tax countries as recipients of royalty transfers from business entities in high-tax countries (Dudar et al., 2015).

Intangible assets have two main characteristics, namely excluding assets that have a physical form also excluding financial assets and can be owned or can be controlled in commercial activities. Intangible assets can also be distinguished in two categories namely trade intangible and marketing intangible (OECD, 2010).

The Development Hypothesis (Bernard et al., 2006) found that U.S. exporters set different prices for reasonable (un related) customers and customers of related parties. Pricing for unblated parties tends to be greater than related parties. This pricing is influenced by the type of goods, the size of the company and the export share of the company, the tax rate of the destination country, as well as changes in the exchange rate against the US dollar. This is contrary to the wishes of fiskus and other tax authorities to ensure that between companies that have a special relationship or who do not have a special relationship will use a reasonable price in every trading transaction so that the fiskus of a country can prevent the potential loss of income from the tax withdrawal sector (Tampubolon \& Al Farizi , 2018).

Parent companies and subsidiaries are separate legal entities from a tax point of view. The two companies arrange transactions in such a way that the company's domestic 
subsidiaries lose out, but the parent company overseas profit (Rahayu, 2010). (Saraswati \& Sujana, 2017) revealed that the tax has a positive effect on transfer pricing. In order to minimize the total corporate group tax burden, a company transfers resources to related entities domiciled overseas in order to reduce profits. The high tax rate of a country is directly proportional to the company's opportunity to implement a transfer pricing mechanism.

Companies with concentrated ownership structures tend to tunnel. This can happen because controlling shareholders have the capacity and incentive to conduct transactions at a special price, protection against the rights of noncontrolling shareholders is still weak, and the strong influence of controlling shareholders on agents in decision-making that maximizes the profit of controlling shareholders and harms noncontrolling shareholders. The majority of shares in public companies in Indonesia are controlled by only a few parties, so controlling shareholders tend to tunnel (Marfuah \& Azizah, 2014).

There are two things that encourage companies to tunnel, namely ownership structures and financial resources. Controlling shareholders can leverage their power and influence to pressure agents to make decisions that side with them. Abundant resources are a stimulus for controlling shareholders in taking tunneling steps for its own sake (Marfuah \& Azizah, 2014). Transfer pricing is done in order to tunneling to noncontrolling shareholders so that they lose. The negative impact of tunneling for the company is the decline in financial performance (Wafiroh \& Hapsari, 2016). Transfer pricing transactions can be done through the sale of inter-affiliated companies (Noviastika F. et al., 2016).

Bonus plan hypothesis explains that if the awarding of bonuses is based on achieving profit, the company's management is more inclined to adopt accounting policies that can maximize the profit of the current period in order to pursue bonuses (Sulistyanto, 2018). Bonus plan is an accounting strategy that aims to appreciate the board of directors for achieving the company's consolidated profit (Mispiyanti, 2015). The distribution of bonuses from the owner is not only aimed at directors who make profit for their divisions or subunits, but also for directors who want to work together to increase the company's consolidated profits (Mispiyanti, 2015). If a bonus is handed on the basis of the company's reported profit, the company tends to manipulate profits through transfer pricing (Lo et al., 2010).

Intangible assets are nonmonary assets that can be identified and have no physical form (Agoes \& Trisnawati, 2013). Bonus plan hypothesis on positive accounting theory suspects that companies that use bonus plan policies are more inclined to choose accounting procedures that will raise profit in the current year (Sulistyanto, 2018). Regarding intangible assets, companies that use bonus plans are more inclined to choose amortization methods that can raise the company's annual profit (Fadhilah, 2018).

Intangible assets are difficult to assess, so the transfer value of payments (royalties) is also difficult to assess based on fair price (Richardson et al., 2013). This loophole can be exploited by companies that use bonus plans to maximize the company's profit achievement by utilizing transfer pricing mechanisms. Multinational corporations strategically relocate their assets to entities located in countries that apply low tax rates to receive royalty transfers from related entities located in countries that apply high tax rates (Dudar et al., 2015). (Fadhilah, 2018) found empirical evidence that intangible assets have a significant positive effect on transfer pricing. The higher the value of intangible assets, the higher the motivation of business entities to implement transfer pricing mechanisms.

Based on the above, the hypothesis in this study is stated as follows.

$\mathrm{H} 1$ : Taxes affect transfer pricing decisions 
$\mathrm{H} 2$ : Tunneling incentive for income shifting affects transfer pricing decisions

H3: Financial Reporting affects transfer pricing decisions

H4: Intangible Assets affect transfer pricing decisions

\section{Research methods}

Data, Population and Sample

This type of research is quantitative research using secondary data in the form of annual financial statements downloaded from the official website of the Indonesia Stock Exchange (IDX) namely www.idx.co.id. The population of this study is a manufacturing company registered in IDX for the period 2016-2018. Samples are selected by nonprobability sampling method with purposive sampling technique.

\section{Definition and measurement of research variables}

\section{Transfer pricing decision}

Is pricing in inter-party transactions that have a special relationship. Transfer pricing decisions are measured using Related Party Transaction /RPT, which is one of the company's strategies in carrying out transfer pricing. The transaction of the sale of products from a subsidiary company to the parent company is done by not taking profit so that the subsidiary company loses and does not have to pay tax charges (Marisa, 2017).

RPT (related party transaction $)=($ total special party receivables $)$

(total receivables)

2. Tax

Is a mandatory contribution to a country owed by a private person or entity that is coercive on the basis of the Act, without obtaining direct benefits and utilized in fulfilling the state's budget for the large welfare of the people The measurement of tax variables using the Effective Tax Rate (ETR) indicator. Policymakers and interest groups often use ETR as a means to make conclusions about the corporate tax system because ETR provides a statistical summary of the cumulative effects of various tax incentives and tax rate changes (Richardson \& Lanis, 2007).

$\mathrm{ETR}=($ tax expense-deffered tax expense $) /($ pretax income)

3. Tunneling Incentive for Income Shifting Tunneling is the transfer of assets and profits outside the company for the benefit of controlling shareholders. Tunneling incentive for income shifting is measured by the ratio of the largest number of shareholdings to the number of shares outstanding. Entities are considered to have a significant influence on other entities if they have a minimum investment capital of $20 \%$, either directly or indirectly (Indonesian Institute of Accountants, 2014a).

TUN=(largest number of shareholdings)/(number of shares outstanding)

\section{Financial Reporting}

Bonus is an additional income aimed at improving employee morale in improving work performance and loyalty to companies that are generally only awarded once a year. The financial reporting (bonus plan) in this study was measured using the ITRENDLB formula, which is a comparison between the amount of net profit in the year $\mathrm{t}$ to the net profit of the year t-1 (Saraswati and Sujana, 2017).

ITRENDLB $=($ net profit for the year $\mathrm{t}) /($ net profit for the year $\mathrm{t}-1)$

5. Intangible assets are nonmonary assets identified without physical form (Agoes \& Trisnawati, 2013). Intangible assets are difficult to assess, so the transfer value of payments (royalties) is also difficult to assess based on fair price (Richardson et al., 2013). Intangible assets are measured by $\log$ formula (Fadhilah, 2018). IA = $\log$ (intangibel assets) 


\section{Data Analysis Techniques}

Data analysis techniques in this study are conducted in several stages namely: Descriptive Statistical Test, Classic Assumption Test consisting of normality test, multicolinerity test, autocor correlation test, and heteroskedastity test, Multiple Linear Regression Test, Hypothesis test consisting of $\mathrm{t}$ test and coefficient determination test (R2) Analysis and Discussion. In this section we will explain the results of tax influence analysis, tunneling incentive for income shifting, financial reporting, and intangible assets against transfer pricing decisions.Uji Statistik Deskriptif

\section{Table 1 Descriptive Statistics Test Results}

Descriptive Statistics
\begin{tabular}{|l|l|l|l|l|l|}
\hline \multicolumn{1}{|l|}{} & $\mathrm{N}$ & Minimum & Maximum & Mean & Std. Deviation \\
\hline PJ & 62 &, 11 &, 40 &, 2537 &, 06361 \\
TUN & 62 &, 21 &, 93 &, 6198 &, 19675 \\
ITRENDLB & 62 &, 36 & 1,87 & 1,0658 &, 34905 \\
IA & 62 & 7,08 & 13,32 & 10,4184 & 1,46725 \\
RPT & 62 &, 00 &, 27 &, 0661 &, 06492 \\
Valid N (listwise) & 62 & & & & \\
\hline
\end{tabular}

Sources: Prepared and computed by the authors

Based on the table of descriptive statistical test results above, it is known that the value of N (amount of data) in each variable ETR, TUN, ITRENDLB, IA, and RPT is 62.

a) The tax variable (ETR) has the smallest value of 0.11 , the largest value of 0.40 , an average value of 0.2537 , and a standard deviation of 0.06361 .

b) The tunneling incentive for income shifting (TUN) variable has the smallest value of 0.21 , the largest value of 0.93 , an average value of 0.6198 , and a standard deviation of 0.19675 .

c) The financial reporting variable (ITRENDLB) has the smallest value of 0.36 , the largest value of 1.87, an average value of 1.0658, and a standard deviation of 0.34905 .

d) The intangible assets (IA) variable has the smallest value of 7.08, the largest value of 13.32, an average value of 10.4184, and a standard deviation of 1.46725 .

e) The transfer pricing decision variable (ETR) has the smallest value of 0.00 , the largest value of 0.27 , an average value of 0.0661 and a standard deviation of 0.06492 .

Normality test

\section{Classic Assumption Test}

Table 2 Normality Test Results

One-Sample Kolmogorov-Smirnov Test

\begin{tabular}{|c|c|c|}
\hline & & $\begin{array}{l}\text { Unstandardized } \\
\text { Residual }\end{array}$ \\
\hline $\mathrm{N}$ & & 62 \\
\hline Normal Parametera a,b & Mean & 0,000000 \\
\hline Normal Parameters a, & Std. Deviation &, 05676106 \\
\hline & Absolute & ,091 \\
\hline Most Extreme Differences & Positive &, 091 \\
\hline & Negative &,- 050 \\
\hline Kolmogorov-Smirnov Z & &, 715 \\
\hline Asymp. Sig. (2-tailed) & &, 686 \\
\hline
\end{tabular}

a. Test distribution is Normal.

b. Calculated from data.

Sources: Prepared and computed by the authors 
Based on table 2 , it is known that the asymp value. sig (2-tailed) is 0.686 . This value shows that the probability of acceptance of 0.686 is greater than the significance level $(0.686>0.05)$, so it can be concluded that the data is normally distributed.Uji Multikolinieritas

Table 3 Multicollinearity Test Results Coefficients $^{\mathrm{a}}$

\begin{tabular}{|ll|l|l|}
\hline Model & & \multicolumn{2}{|l|}{ Collinearity Statistics } \\
\cline { 3 - 4 } & & Tolerance & VIF \\
\hline \multirow{4}{*}{1} & (Constant) & & \\
& ETR & 967 & 1,034 \\
& TUN & 932 & 1,073 \\
& ITRENDLB & 986 & 1,015 \\
& IA & 947 & 1,056 \\
\hline
\end{tabular}

a. Dependent Variable: RPT

Sources: Prepared and computed by the authors

Based on table 3, it is known that the tolerance value $>0.10$ and VIF $<10$ for all variables, so it can be concluded that there is no multicollinearity symptom.Uji Autokorelasi

Table 4 Autocorrelation Test Results

\begin{tabular}{|l|}
\hline \multicolumn{1}{|c|}{ Model Summary $^{\mathrm{b}}$} \\
Model $\quad$ Durbin-Watson \\
$\quad 2,086$ \\
$\begin{array}{l}\text { a. Predictors: (Constant), LAG_X4, LAG_X1, LAG_X2, } \\
\text { LAG_X3 } \\
\text { b. Dependent Variabel: LAG_Y }\end{array}$
\end{tabular}

Sources: Prepared and computed by the authors

Based on table 4, it is known that the calculated d value (durbin-watson) is 2.086. The $\mathrm{dL}$ and $\mathrm{dU}$ values according to the DW table are 1.4554 and 1.7288 , respectively.

$$
\mathrm{dU}<\mathrm{d}<4-\mathrm{dU} \rightarrow 1,7288<2,086<2,2712
$$

The conclusion that can be drawn from the results above is that there is no autocorrelation in this study.Uji Heterokedastisitas 


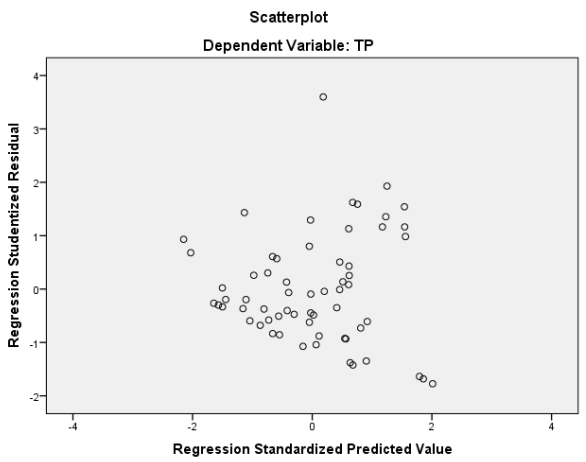

Figure 1 Heteroscedacity test results

Based on Figure 1, it is known that there is no clear pattern and the distribution of dots is evenly distributed above and below the number 0 on the $\mathrm{Y}$ axis, so it can be concluded that in this study there is no heteroscedasticity.

\section{Multiple Linear Regression Analysis}

Table 5 Multiple Linear Regression Analysis Test Results Coefficients $^{\mathrm{a}}$

\begin{tabular}{|ll|l|l|l|}
\hline \multicolumn{2}{|l|}{ Model } & \multicolumn{2}{|l|}{ Unstandardized Coefficients } & $\begin{array}{l}\text { Standardized } \\
\text { Coefficients }\end{array}$ \\
\cline { 3 - 5 } & & B & Std. Error & Beta \\
\hline \multirow{3}{*}{1} & (Constant) &,- 117 &, 079 & \\
& ETR &,- 042 &, 120 &,- 041 \\
& TUN &,- 027 &, 040 &,- 081 \\
& ITRENDLB &, 000 &, 022 &,- 002 \\
& IA &, 020 &, 005 &, 458 \\
\hline
\end{tabular}

a. Dependent Variable: RPT

Sources: Prepared and computed by the authors

Based on the results of the statistical hypothesis test in Table 5, the results of the multiple linear regression equation are as follows:

$$
\text { RPT }=-0,117-(0.042) \text { ETR-(0.027)TUN }+(0.000) I T R E N D L B+(0.020) I A+e
$$

The regression equation above can be described as follows:

a) The constant of the regression equation is -0.117 , which means that if the four independent variables, namely tax (ETR), tuneling incentive for income shifting (TUN), financial reporting (ITRENLB), and intangible assets (IA) the changes are equal to zero, then the decision transfer pricing (RPT) decreased by 0.117 .

b) The regression coefficient of the tax variable (ETR) is -0.042 . This means that every one-unit increase in the tax variable, a decrease in the transfer pricing decision will be followed by 0.042 . Conversely, for every one-unit decrease in the tax variable, an increase in transfer pricing decision will be followed by 0.042 .

c) The regression coefficient of the tunneling incentive for income shifting (TUN) variable is $-0,027$. This means that every one unit increase in the tunneling incentive for income shifting variable, a decrease in transfer pricing decision will be followed by 0.027. Conversely, for every one-unit decrease in the tunneling incentive for income 
shifting variable, an increase in transfer pricing decision will be followed by 0.027 .

d) The regression coefficient of the financial reporting variable (ITRENLB) is 0,000 .

This means that every one-unit increase in the financial reporting variable, an increase in the transfer pricing decision will be followed by 0,000 . Conversely, for every oneunit decrease in the financial reporting variable, a decrease in the transfer pricing decision will be followed by 0,000 .

e) The regression coefficient of the intangible assets (IA) variable is 0.020 . This means that every one-unit increase in the intangible assets variable, an increase in transfer pricing decision will be followed by 0.020 . Conversely, for every one-unit decrease in the intangible assets variable, a decrease in transfer pricing decision will be followed by 0.020 .

\section{Hypothesis Testing}

\section{Statistical test $\mathrm{t}$}

\section{Table 6 Statistical Test Results $t$}

Coefficients $^{\mathrm{a}}$

\begin{tabular}{|ll|l|l|l|l|l|}
\hline \multirow{2}{*}{ Model } & \multicolumn{2}{|l|}{$\begin{array}{l}\text { Unstandardized } \\
\text { Coefficients }\end{array}$} & $\begin{array}{l}\text { Standardized } \\
\text { Coefficients }\end{array}$ & Sig. \\
\cline { 3 - 5 } & & & $\begin{array}{l}\text { Std. } \\
\text { Error }\end{array}$ & Beta & \\
\hline \multirow{4}{*}{1} & (Constant) &,- 117 &, 079 & & $-1,480$ &, 144 \\
& ETR &,- 042 &, 120 &,- 041 &,- 352 &, 726 \\
& TUN &,- 027 &, 040 &,- 081 &,- 675 &, 502 \\
& ITRENDLB &, 000 &, 022 &,- 002 &,- 020 &, 984 \\
& IA &, 020 &, 005 &, 458 & 3,849 &, 000 \\
\hline
\end{tabular}

a. Dependent Variable: RPT

Sources: Prepared and computed by the authors

Based on the results of the $t$ statistical hypothesis test in table 6 , it can be concluded that the effect of each independent variable on the dependent variable is as follows:

1) The Tax Variable (ETR) has tcount $<$ ttable which is $-0.352<2.00247$ and has a significance value greater than the $\alpha$ value, namely $0.726>0.05$. Thus, HA1 is rejected. 2) The tunneling incentive for income shifting (TUN) variable has tcount $<$ ttable, which is $-0.675<2.00247$ and has a significance value greater than the $\alpha$ value, namely $0.502>$ 0.05 . Thus, HA2 is rejected.

3) The financial reporting variable (ITRENDLB) has tcount $<$ ttable, which is -0.020 $<2.00247$ and has a significant value greater than the $\alpha$ value, namely $0.984>0.05$. Thus, HA3 is rejected.

4) The intangible assets (IA) variable has tcount $>$ ttable that is 3,849>2,00247 and has a smaller significance value than the $\alpha$ value, which is $0,000<0.05$. Thus, HA4 is accepted.

Test the coefficient of determination (R2)

Table 7 The Result of Determination Coefficient Test

Model Summary ${ }^{\mathrm{b}}$

\begin{tabular}{|l|l|l|l|l|}
\hline Model & $\mathrm{R}$ & R Square & Adjusted R Square & $\begin{array}{l}\text { Std. Error of the } \\
\text { Estimate }\end{array}$ \\
\hline 1 &, $485^{\mathrm{a}}$ &, 235 &, 182 &, 05872 \\
\hline
\end{tabular}

a. Predictors: (Constant), IA, ITRENDLB, ETR, TUN

b. Dependent Variable: RPT

Sources: Prepared and computed by the authors 
Based on table 7, it can be seen that the value of Adjusted R2 is 0.182 , which means that the variation in the dependent variable that can be explained by the independent variable is $18.2 \%$. This means that the independent variables which include taxes, tunneling incentives for income shifting, financial reporting, and intangible assets affect transfer pricing decisions by $18.2 \%$, while the remaining $81.8 \%$ are influenced by other variables not examined in this study.

\section{Discussion}

\section{The Effect of Taxes on Transfer Pricing Decisions}

Based on the results of the $t$ statistical test, it can be concluded that taxes have no effect on transfer pricing decisions. Indonesia applies a corporate income tax rate of $25 \%$ for the 2016-2018 period. However, the sample companies did not choose transfer pricing as a tax saving mechanism. These results support Melmusi (2016), who suspects that the sample companies have implemented a tax saving mechanism through tax planning activities, which is to make the tax burden as low as possible in the existing tax regulations.

This result is contrary to Kusumasari et al. (2018), Klassen et al. (2013) and Richardson et al. (2013) who found that the high corporate tax rate imposed by a country is directly proportional to the company's decision to transfer corporate profits to a tax heaven country through the transfer pricing mechanism.

2. Effect of Tunneling Incentive for Income Shifting on Transfer Pricing Decisions Based on the results of the $t$ statistical test, it can be concluded that tunneling incentive for income shifting has no effect on transfer pricing decisions. The results of this study support Ayshinta's (2019) research which states that the absence of the effect of tunneling incentive for income shifting on transfer pricing decisions indicates that controlling shareholders do not take advantage of their control rights to give orders to management to carry out transfer pricing. Wiratno (2017) states that this indicates that a large percentage of share ownership is not a benchmark in a company's decision to carry out transfer pricing. Thus, the interest of the controlling shareholder to increase personal gain is no longer relevant because the special relationship is not formed as a result of a blood relationship, so that expropriation is difficult to realize because the approval of the board of directors is required in making managerial decisions.

The absence of the effect of tunneling incentives for income shifting on transfer pricing decisions can also be used as a reference for the effectiveness of the supervisory mechanism implemented by the company. Brundy (2014) divides the supervisory mechanism into two categories, namely internal and external. The internal control mechanism is through the board of commissioners, especially those dominated by the independent board of commissioners. Tunneling can be suppressed by the board of commissioners by authorizing transactions deemed material and improper. The external supervisory mechanism is through creditors and independent auditors. Creditors have a risk of uncollectible debt so they are authorized to supervise the company's performance and can ask for debt repayment at any time if the company violates the debt agreement. Meanwhile, independent auditors are responsible to the general public to provide professional opinions on financial reports published by the company.

This study contradicts Lo, et al. (2010) who found that tunneling incentives for income shifting have an effect on transfer pricing decisions. The profit shift increases in proportion to the percentage of ownership of the controlling shareholder.

3. The Effect of Financial Reporting on Picing Transfer Decisions

Based on the results of the $t$ statistical test, it can be concluded that financial reporting has no effect on transfer pricing decisions. This research supports Wiratno (2017), which indicates that the high ITRENDLB value means that the current year's profit is greater than the previous period's profit. The average value of INTRENDLB in this 
study is $106.58 \%$, so it can be categorized as tending to be stable. The stability of the ITRENDLB value indicates the company's lack of interest in manipulating profits through transfer pricing to increase bonuses.

A good stakeholder supervision mechanism also suppresses the unexpected spike in profit due to transfer pricing. The competence of the audit committee in the areas of accounting and finance will affect the effectiveness of supervision of management so that manipulative managerial actions can be quickly identified and addressed (Saraswati \& Sujana, 2017).

This result contradicts Lo et al. (2010) who found empirical evidence that company managers tend to use transfer pricing to increase profits if companies implement a profit-based bonus mechanism. Hartati et al. (2014) also found the tendency of directors to do their best to increase overall company profits, one of which is through the transfer pricing mechanism, in connection with the company owner's policy to provide bonuses based on overall profit achievement.

4. The effect of intangible assets on transfer pricing decisions

Based on the results of the $t$ statistical test, it can be concluded that the effect of intangible assets is directly proportional to the transfer pricing decision. The greater the intangible asset value of a company, the greater the company's decision to carry out transfer pricing. These results support Anggraini's (2018) research which states that the high transfer pricing transactions are due to the inequality in interpreting the value of transfer prices and the difficulty in determining the right definition for intangible asset transactions. The level of difficulty in measuring an intangible asset is directly proportional to the company's tendency to apply the transfer pricing mechanism. The difficulty in measuring intangible assets creates opportunities for le companies to transfer profits to a tax heaven country through transfer payments (royalties) which are difficult to measure using the arm's length principle (Dudar, 2015). Companies in Indonesia tend to ignore research and development, even though $\mathrm{R} \& \mathrm{D}$ is closely related to intangible assets. Moreover, the database of the transfer pricing mechanism, especially on intangible assets, is still lacking (Fadhilah, 2018).

The results of this test contradict the research of Deanti (2017) and Jafri and Mustikasari (2018) where both studies suggest that there is no influence of intangible assets on transfer pricing decisions. The amount of intangible assets of a company does not motivate management to take the transfer pricing mechanism. The valuation of the company by investors solely takes into account the high intensity of R\&D and the value of intangible assets and ignores the increase in the company's financial performance due to the utilization of the company's intangible assets.

\section{Conclusions and Recommendations}

Based on the results of hypothesis testing, the following conclusions can be drawn:

1. Taxes have no effect on transfer pricing decisions. These results provide evidence that tax is not the main reason companies apply transfer pricing.

2. Tunneling Incentive for Income Shifting has no effect on transfer pricing decisions. These results prove that the percentage of share ownership is not a benchmark in the decision to carry out transfer pricing.

3. Financial Reporting has no effect on transfer pricing decisions. The stability of the ITRENDLB value of the sample companies shows that the company is less interested in manipulating earnings (earning management) through transfer pricing as an effort to maximize bonus.

4. Intangible Assets have a significant positive effect on transfer pricing decisions. This result means that the greater the intangible assets, the company's transfer pricing decision will also increase.

Some limitations are still found in this study, including the following: 
1. The observation period is relatively short, namely three years, so that the results obtained do not provide a complete picture of the effect of the independent variable on the dependent variable.

2. The parameters used are still limited to the information provided by the company in the annual report. However, not all companies include the required information, especially information regarding intangible assets, so that many companies do not pass the sample selection criteria.

Further research is recommended for

1. Adding independent variables that have a big influence on transfer pricing decisions, for example Good Corporate Governance (GCG) and debt covenants.

2. Extending the research period, in order to get a better picture of the effect of independent variables on transfer pricing decisions.

3. Expanding the population so that research results can reach more corporate sectors.

\section{References}

Agoes, S., \& Trisnawati, E. (2013), Akuntansi Perpajakan (3rd ed.). Salemba Empat.

Aharony, J., Wang, J., \& Yuan, H. (2010), Tunneling as An Incentive for Earnings Management during The IPO Process in China. Journal of Accounting and Public Policy, 29, 1-26. https://doi.org/10.1016/j.jaccpubpol.2009.10.003.

Anthony, R. N., \& Govindarajan, V. (2011), Sistem Pengendalian Manajemen (12th ed.). Karisma Publishing Group.

Bernard, A. B., Jensen, J. B., \& Schott, P. K. (2006), Transfer Pricing by US-Base Multinational Firms (NBER Working Paper No. 12493).

Dudar, O., Spengel, C., \& Voget, J. (2015), The Impact of Taxes on Bilateral Royalty Flows. In ZEW Discussion Papers.

Fadhilah, M. A. (2018), Pengaruh Pajak dan Intangibel Assets terhadap Motivasi Perusahaan Melakukan Transfer Pricing. Universitas Islam Indonesia.

Gilson, R. J., \& Gordon, J. N. (2003), Doctrines and Markets. University of Pensylvania Law Review, Vol. 152:, 785-843.

Hartati, W., Desmiyawati, \& Julita. (2014), Tax Minimization, Tunneling Incentive dan Mekanisme Bonus terhadap Keputusan Transfer Pricing Seluruh Perusahaan yang Listing di Bursa Efek Indonesia. In Simposium Nasional Akuntansi XVIII Medan (Issues 16-19 September).

Healy, P. M. (1985), The Effect of Bonus Schemes on Accountings Decision. Journal of Accounting and Economics, 7, 85-107.

Ikatan Akuntan Indonesia. (2014a), Pernyataan Standar Akuntansi Keuangan Nomor 15 tentang Investasi pada Entitas Asosiasi dan Ventura Bersama. In Standar Akuntansi Keuangan Per Efektif 1 Januari 2015. Ikatan Akuntan Indonesia.

Ikatan Akuntan Indonesia. (2014b), Pernyataan Standar Akuntansi Keuangan Nomor 19 tentang Aset Tak Berwujud. In Standar Akuntansi Keuangan Per Efektif 1 Januari 2015. Ikatan Akuntan Indonesia.

Ikatan Akuntan Indonesia. (2014c), Pernyataan Standar Akuntansi Keuangan Nomor 24 tentang Imbalan Kerja. In Standar Akuntansi Keuangan Per Efektif 1 Januari 2015. Ikatan Akuntan Indonesia.

Ikatan Akuntan Indonesia. (2014d), Pernyataan Standar Akuntansi Keuangan Nomor 7 tentang Pengungkapan Pihak-Pihak Berelasi. In Standar Akuntansi Keuangan Per Efektif 1 Januari 2015. Ikatan Akuntan Indonesia.

Jacob, J. (1996), Taxes and Transfer Pricing: Income Shifting and the Volume of Intrafirm Transfers. Journal of Accounting Research, 34 (Autumn 1996). https://doi.org/10.2307/2491504.

Johnson, S., La Porta, R., Lopez de Silanes, F., \& Shleifer, A. (2000), Tunneling. The 
near Crash of 1998 AEA Papers and Proceedings, vol 90 no, 22-27.

Kementerian Perindustrian Republik Indonesia. (2018), Industri Manufaktur Setor Pajak Terbesar Hingga Rp 103 Triliun. Https://Kemenperin.Go.Id/.

Kurniawan, A. M. (2015), Transfer Pricing untuk Kepentingan Pajak. Andi Offset.

La Porta, R., Lopez-De-Silanes, F., Shleifer, A., \& Vishny, R. (2000), Investor Protection and Corporate Governance. Journal of Financial Economics. https://doi.org/10.2469/dig.v31.n2.870

Lo, A. W. Y., Wong, R. M. K., \& Firth, M. (2010), Tax, Financial Reporting, and Tunneling Incentives for Income Shifting: An Empirical Analysis of The Transfer Pricing Behavior of Chinese-Listed Companies. Journal of the American Taxation Association. https://doi.org/10.2308/jata.2010.32.2.1

Mardiasmo (2016), Perpajakan Edisi Terbaru 2016. Andi Offset.

Marfuah, \& Azizah, A. P. N. (2014), Pengaruh Pajak, Tunneling Incentive dan Exchange Rate pada Keputusan Transfer Pricing Perusahaan. JAAI, 18 No 2 (Desember 2014), 156-165.

Marisa, R. (2017), Pengaruh Pajak, Bonus Plan, Tunneling Incentive, dan Ukuran Perusahaan terhadap Transfer Pricing. Jurnal Akuntansi Unesa.

Merchant, K. A., \& Van der Stede, W. A. (2018), Sistem Pengendalian Manajemen Pengukuran Kinerja, Evaluasi, dan Insentif (3rd ed.). Salemba Empat.

Mispiyanti. (2015), Pengaruh Pajak dan Mekanisme Bonus terhadap Keputusan Transfer Pricing. Pengaruh Pajak, Tunneling Incentive Dan Mekanisme Bonus Terhadap Keputusan Transfer Pricing.

Mulyapradana, A., \& Hatta, M. (2016), Pekerja Melek Hukum, Jadi Karyawan Kaya: Genius Mengetahui \& Mengelola Hak Keuangan Karyawan (L. Sutinah (ed.). Visimedia.

Noviastika F., D., Mayowan, Y., \& Karjo, S. (2016), Pengaruh Pajak, Tunneling Incentive dan Good Corporate Governance (GCG) terhadap Indikasi Melakukan Transfer Pricing pada Perusahaan Manufaktur yang Terdaftar di Bursa Efek Indonesia. Jurnal Perpajakan (JEJAK)|.

OECD (2010), Transfer Pricing Guidelines for Multinational Enterprises and Tax.

Peraturan Bank Indonesia, Pub. L. No. 14/ 24 /PBI/2012 tentang Kepemilikan Tunggal pada Perbankan Indonesia (2012).

Peraturan Direktur Jenderal Pajak, Pub. L. No. PER-32/PJ/2011 tentang Perubahan atas Peraturan Dirjen Pajak No PER-43/PJ/2010 tentang Penerapan Prinsip Kewajaran dan Kelaziman Usaha dalam Transaksi antara Wajib Pajak dengan Pihak yang Mempunyai Hubungan Istimewa (2011).

Pohan, C. A. (2013), Manajemen Perpajakan Strategi Perencanaan Pajak dan Bisnis (revisi). Gramedia Pustaka Utama.

Primadhyta, S. (2017, February 2), Transfer Pricing Sunat Pajak, Dokumen Perusahaan Diperketat. https://www.cnnindonesia.com/ekonomi/20170202154249-78190886/transfer-pricing-sunat-pajak-dokumen-perusahaan-diperketat

Rahayu, N. (2010), Praktik Penghindaran Pajak oleh Foreign Direct Investment Berbentuk Perseroan Terbatas Penanaman Modal Asing. Jurnal Ilmu Administrasi Negara, 10 Nomor 2(Juli 2010), 171-180.

Rahmawati, S. (2016), Konflik keagenan dan Tata Kelola Perusahaan di Indonesia (S. Dr Faisal (ed.)). Syah Kuala University Press.

Refrizal. (2019), Pendapatan Negara Didominasi Perpajakan. Http://Www.Dpr.Go.Id/. Richardson, G., \& Lanis, R. (2007), Determinants of The Variability in Corporate Effective Tax Rates and Tax Reform: Evidence from Australia. Journal of Accounting and Public Policy, 26, 689-704.

Richardson, G., Taylor, G., \& Lanis, R. (2013), Determinants of Transfer Pricing Aggressiveness: Empirical Evidence from Australian Firms. Journal of Contemporary Accounting and Economics. 
https://doi.org/10.1016/j.jcae.2013.06.002

Saraswati, G. A. R. S., \& Sujana, I. K. (2017), Pengaruh Pajak, Mekanisme Bonus, dan Tunneling Incentive pada Indikasi Melakukan Transfer Pricing. E-Jurnal Akuntansi Universitas Udayana, Vol.19.2 (Mei (2017)), 1000-1029.

Setiawan, H. (2014), Transfer Pricing dan Risikonya Terhadap Penerimaan Negara. Https://Www.Kemenkeu.Go.Id/.

Suandy, E. (2016), Perencanaan Pajak. Salemba Empat.

Sulistyanto, H. S. (2018), Manajemen Laba. Grasindo.

Supramono, \& Damayanti, T. W. (2010), Perpajakan Indonesia-Mekanisme dan Perhitungan (R. Fiva (ed.)). Andi Offset.

Surat Edaran Direktur Jenderal Pajak, Pub. L. No. SE-04/PJ.7/1993 Tentang Petunjuk Penanganan Kasus-Kasus Transfer Pricing (1993).

Suwanto, S. (2012), Analisa Transfer Pricing: Aset Tak Berwujud (Intangibels).

Tampubolon, K., \& Al Farizi, Z. (2018), Transfer Pricing dan Cara Membuat TP Doc. Deepublish.

Undang-undang Republik Indonesia, Pub. L. No. 36 Tahun 2008 tentang Perubahan Keempat atas Undang-Undang Nomor 7 Tahun 1983 tentang Pajak Penghasilan (2008).

Undang-Undang Republik Indonesia, Pub. L. No. 16 Tahun 2009 tentang Penetapan Peraturan Pemerintah Pengganti Undang-Undang No 5 Tahun 2008 tentang Perubahan Keempat atas Undang-Undang No 6 Tahun 1983 tentang Ketentuan Umum dan Tata Cara Perpajakan menjadi Undang-Undang (2009).

Wafiroh, N. L., \& Hapsari, N. N. (2016), Pajak, Tunneling Incentive dan Mekanisme Bonus pada Keputusan Transfer Pricing. El Muhasaba: Jurnal Akuntansi. https://doi.org/10.18860/em.v6i2.3899 